\title{
Insulin Resistance on The Influence of Thyroid Hormone Levels
}

\author{
Luiz Augusto da Silva* \\ Department of Physical Education, Faculdade Guairacá, Brazil
}

Submission: May 12 2018; Published: August 09, 2018

*Corresponding author: Luiz Augusto da Silva, Department of Physical Education, Faculdade Guairacá, Guarapuava, Paraná, Brazil, Email: lasilva7@hotmail.com

\section{Introduction}

Thyroid hormones (TH) are important determinants of glucose homeostasis [1,2], and in contrast, insulin is the first hormone responsible for glycemic control, and there may be an effect between $\mathrm{T} 3$ and insulin determining pathways of glucose and lipid metabolism [3].

In the present study, the effect of insulin on insulin secretion and insulin sensitivity on insulin sensitivity and insulin sensitivity in patients with diabetes mellitus. Lambardiari et al. [3] evaluated euthyroid subjects in the early stages of diabetes mellitus (DM) and insulin resistance (IR), investigating the association of TH levels with glucose sensitivity by insulin metabolism, and it was found that $\mathrm{T} 3$ and $\mathrm{T} 4$ levels were reduced in subjects with DM compared to the control group.

The results of $\mathrm{T} 3$, increased during exercise and reduced after exercise associated with caffeine, demonstrate a new context, and can be determined by fluctuations of glycemic and lipid, corticosterone and insulin, and may have characteristic effects within metabolic homeostasis. A network of adrenergic innervation in the thyroid gland stimulates the control of the activation and release of $\mathrm{TH}$, influencing the thyroid stimulant hormone (TSH) stimulation response [4].

Catecholamines (corticosterone, adrenaline) increase the conversion of T4 into T3 by the specific activity of the enzyme deubiquitinase that acts on the upregulators activity of the protein deubiquitin 2, increasing T3 levels in the thyroid cell nucleus [5]. This synergism between TH and the sympathetic nervous system (SNS) may be involved in changes in stock or energy release [6]. During exercise, the adrenergic action correlates with the increase of catecholamines, which can increase the values and conversions of T4 in T3. The focus of TH on energy action as well as regulation of lipid and carbohydrate metabolism pathways describe the influence of these hormones on pathological conditions such as DM.

TH inhibits the release of glucose-stimulated insulin, associated with SNS actions, leading to increased islet glucose oxidation and utilization, thus describing a negative feedback action
[7]. This stimulus is due to the adrenergic action on the thyroid gland, increasing the release and conversion of TH and consequent glycemic increase. In contrast, T3 treatment prevents deterioration and maintains $\beta$-cell structure, size and consistency of streptozotocin-induced animals [8], leading to increased insulin release. T3 treatment reversed hyperinsulinemia, but not hyperglycemia, in obese animals [9]. Thus, THs act on the maturation and development of $\beta$-cells but controlling the release of insulin due to synergistic stimulation with the SNS, maintaining glycemic homeostasis.

An important understanding has been made about the actions of TH mediating DM-related metabolic actions, acting on several glands and regulator tissues of energy substrates, as well as the actions of caffeine and physical exercise are inherent to the knowledge and treatment of DM. Some themes, such as the action of TH on the ionic regulation in cells altering actions in different pathways, as well as acting on a negative feedback by downregulations on the insulin action, but increasing the proliferation of pancreatic $\beta$ cells, point out important directions in the research. The mechanisms of action related to the thyroid hormones and insulinotropic action form a counterbalance, where an imbalance (hyper or hypothyroidism) can be observed the presence of DM or IR.

\section{References}

1. Kim SR, Tull ES, Talbott EO, Vogt MT, Kuller LH (2002) A hypothesis of synergism: the interrelationship of T3 and insulin to disturbances in metabolic homeostasis. Med Hypotheses 59(6): 660-666.

2. Wennlund A, Felig P, Hagenfeldt L, Warhen J (1986) Hepatic glucose production and splanchnic glucose exchange in hyperthyroidism. J Clin Endocrinol Metab 62(1): 174-180.

3. Lambadiari V, Mitrou P, Maratou E, Raptis AE, Tountas N, et al. (2011) Thyroid hormones are positively associated with insulin resistance early in the development of type 2 diabetes. Endocrine 39(1): 28-32.

4. Sundler F, Grunditz T, Hakanson R, Uddman R (1989) Innervation of the thyroid. A study of the rat using retrograde tracing and immunocytochemistry. Acta Histochem Suppl 37: 191-198.

5. Gereben B, Zavacki AM, Ribich S, Kim BW, Huang SA, et al. (2008) Cellular and molecular basis of deiodinase-regulated thyroid hormone signaling. Endocr Rev 29(7): 898-938. 
6. Ribeiro MO, Carvalho SD, Schultz JJ, Chiellini G, Scanlan TS, et al (2001) Thyroid hormone-sympathetic interaction and adaptive thermogenesis are thyroid hormone receptor isoform-specific. J Clin Invest 108(1): 97-105.

7. Mullur R, Liu YY, Brent GA (2014) Thyroid hormone regulation of metabolism. Physiol Rev 94(2): 355-382.

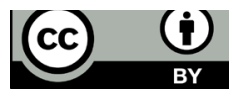

This work is licensed under Creative Commons Attribution 4.0 Licens

DOI: 10.19080/JETR.2018.03.555623
8. Verga Falzacappa C, Mangialardo C, Madaro L, Ranieri D, Lupoi L, et al. (2011) Thyroid hormone T3 counteracts STZ induced diabetes in mouse. PloS One 6(5): e19839.

9. Torrance CJ, Devente JE, Jones JP, Dohm GL (1997) Effects of thyroid hormone on GLUT4 glucose transporter gene expression and NIDDM in rats. Endocrinology 138(3): 1204-1214.

Your next submission with Juniper Publishers will reach you the below assets

- Quality Editorial service

- Swift Peer Review

- Reprints availability

- E-prints Service

- Manuscript Podcast for convenient understanding

- Global attainment for your research

- Manuscript accessibility in different formats ( Pdf, E-pub, Full Text, Audio)

- Unceasing customer service

Track the below URL for one-step submission https://juniperpublishers.com/online-submission.php 